\title{
CONSIDERATIONS ON THE IMPACT OF SUSTAINABLE DEVELOPMENT ON TOURISM PHENOMENON
}

\author{
Nicoleta Georgeta BUGNAR, Liana-Eugenia MEȘTER, Andreea-Florina FORA \\ Faculty of Economic Sciences, University of Oradea, Oradea, Romania \\ nicoleta.bugnar@gmail.com \\ Imester@uoradea.ro \\ andreea.fora@gmail.com
}

\begin{abstract}
Since 2010, the European Commission, through the Communication "Europe, No1 World Tourism Destination - A New Political Framework for Tourism in Europe", has drawn the attention to the fact that local / urban tourism strategies should be essential to the way in which cities promote or limit the extension of tourism services; thus, the increase in the number of tourists in cities and the lack of local tourism policies can lead to negative pressures on the local (environmental, cultural and social) environment.

In the research, we will analyze how the explosive economic growth trend of the analyzed region (in our case due to the massive absorption of European funds for urban infrastructure and for industrial development) has positively or negatively affected the tourism sector of the area. The objective of the research will be: identification of local officials with the elaboration and implementation of sustainable tourism policies related to sustainability and identification of specific factors of influence - local vision on sustainability, local action instruments and, implicitly, the tourist flow generated compared to the economic growth level of the region.
\end{abstract}

From a methodological point of view, the research combines two levels of analysis: the comparative analysis of local economic development plans and strategies with local tourism policies as well as the comparative analysis of economic growth indicators of the region with the tourism indicators for the chosen period.

A comparison between local development strategies and local tourism policies allows us to identify whether the growth of the tourist phenomenon in the region is a mere consequence of the development of the region or it is based on a strategic thinking of tourism development. The idea behind this research is based on the fact that other studies have demonstrated that the notion of sustainable tourism in major European cities remains out of the local political agenda, without discussing possible conflicts between urban tourism and negative externalities.

Keywords: sustainable development, economic growth, tourism, local policies.

\section{JEL Classification: J61}

\section{Sustainability challenges identified in tourist cities}

The increase in the number of tourists and, implicitly, in the accommodation capacity in the big European cities has led to an accentuation of the pressure on the (limited) urban / rural resources and the challenge of the coexistence between residents and visitors. The way in which the development of cities / tourist areas 
has been planned and managed in the last decades has had as a consequence the amplification of the conflicts with the local population (Colomb, C. and Novy, J. (2017).

The analysis of current tourism policies in major European tourist destinations reveals that only a few of them address the conflicts between tourism and the negative consequences generated. Increasing tourism remains a priority for all European local communities.

The sustainability approach in the development of tourism is particularly sensitive because tourism is an important element in the use of resources, in social and environmental changes (Rutty, M. et al. 2014). Therefore, the implementation of sustainable tourism policies remains the main task for the coming years. The contemporary tourism system is characterized by a massive growth, where fast and cheap travel, affordable accommodation facilitates this massive mobility of international and domestic tourism (Williams, A. 2013, 511-53). The increase in investment, hotel construction, technological innovations attract even more tourists to big cities. European Union countries host $40 \%$ of international tourism, especially in the Mediterranean and Western Europe, and are expected to grow from 448 million to 762 million by 2030 (UNWTO, 2018).

Thus, sustainable tourism policies become essential for how cities / areas promote or limit the expansion of tourism-oriented services (accommodation, retail, and hospitality) in and around the city. Tourists and residents share limited space, but "visitors' use of local facilities that were not built for them" can cause problems. (Ashworth, G. and Page, S.J., 2011, 1-15). In this context, the increasing number of tourists in cities and the seasonality of tourism can lead to a stronger pressure on the local environment.

The side impacts of tourism contribute, in many cases, to the negative perception of residents against the development of tourism, which is becoming a contested phenomenon in cities around the world. Urban changes oriented towards tourist attractiveness have created negative externalities at the level of the local community (Colomb, C. and Novy, J., 2017).

A higher density of tourists has a direct impact on:

- Real estate market - due to the increase in the number of buildings / rooms meant for tourism and new hotels in specific urban areas will increase the average price of housing;

- Resident-oriented services - they may suffer from hospitality, cultural and retail services for visitors;

- The quality of the environment (C02, PM, NOx, SOx etc.) - due to the transport of tourists (coaches; private vans; cruises and aviation);

- Increasing waste (plastic, food, energy, water etc.) - these are produced by tourists and industry;

- Water and energy resources.

In the literature, based on the experience of large European metropolises, development trends have been identified, which if not carefully controlled are opposed to the concept of sustainability.

- Overcrowding and pressure in very popular tourist areas.

- Socio-demographic development of very popular tourist areas.

- Increasing tourism in cities.

- Increasing sensitivity to the geopolitical situation. 
- The use of metropolitan infrastructures by tourists.

- New intermediaries and tourist activities.

- Increasing the offers and new types of tourist accommodation.

- Increasing the relative influence of tourism on the world economy.

- New profiles of tourists, visitors, and residents.

- Changes in residents' perception of tourism.

On the other hand, out of the desire for financial gain and to occupy a leading position in the international tourism sector, the challenges to which city managers must respond are: increasing transport capacity and infrastructure, increasing the number of accommodation in order to receive more tourists, the need to diversify the offer both in space and time as traditional tourist places are saturated, the need to innovate to improve visitor satisfaction.

\section{Integrating sustainability into tourism policies}

In general, it has been found that environmental and social sustainability is not sufficiently embedded in tourism development policies. Tourism is present in local development plans only through quantitative indicators, very rarely through crosscutting integration in community development.

In the Development Plan for Barcelona (Tourism Strategic Plan, Tourism Mobility Plan - https://ajuntament.barcelona.cat/turisme/en/strategic-plan/documents and Special Tourism Accommodation Plan http://ajuntament.barcelona.cat/plaallotjaments-turistics/es) sustainability is linked to the city and not only to the destination competitiveness. Sustainability is one of the seven initial provisions of the plan; In Lisbon, the Strategic Tourism Plan for the Lisbon Region 2015-2019 (Câmara Municipal de Lisboa, 2017) focuses on economic and marketing issues, sustainability criteria are not explicitly present in Lisbon. In Paris, (Tourism Strategy 2022 Plan - https://pro.parisinfo.com/actualites/actualite-touristique/Dossiers/ schema-touristique-paris-2022) sustainability is mainly related to the quality of life of local citizens, and in terms of "sustainable tourism development" the specific objectives and action plans remain unclear.

Another issue of sustainability in tourism is related to the deadline for implementing local development strategies. Sustainable development must be seen as a longterm strategy, which runs counter to local development policies (usually lasting 4-6 years) that tend to correspond to political mandates. The question is who should take care of the sustainability of tourist destinations - the leaders of local communities or public stakeholders. In general, in Europe, tourism strategies are designed by local governments, with the exception of Barcelona where we have a more diverse and shared leadership between private and public sector stakeholders (Dredge, D and all, 2016).

The creators of tourism strategies have concluded that, in addition to basic tourism services (transport, accommodation, restaurant), to achieve sustainability in this area must be carefully analyzed other key areas, such as urban planning, local transport and mobility. For example, stakeholders in Barcelona and Lisbon mentioned as defining elements for sustainable development: the local economy, jobs and business, transport and mobility, urbanism and tourism (Vera Pais, 2018). For Paris, the areas of interest are urbanism, tourism, mobility and transport (Marie de Paris (2016) - see Figure 1. 


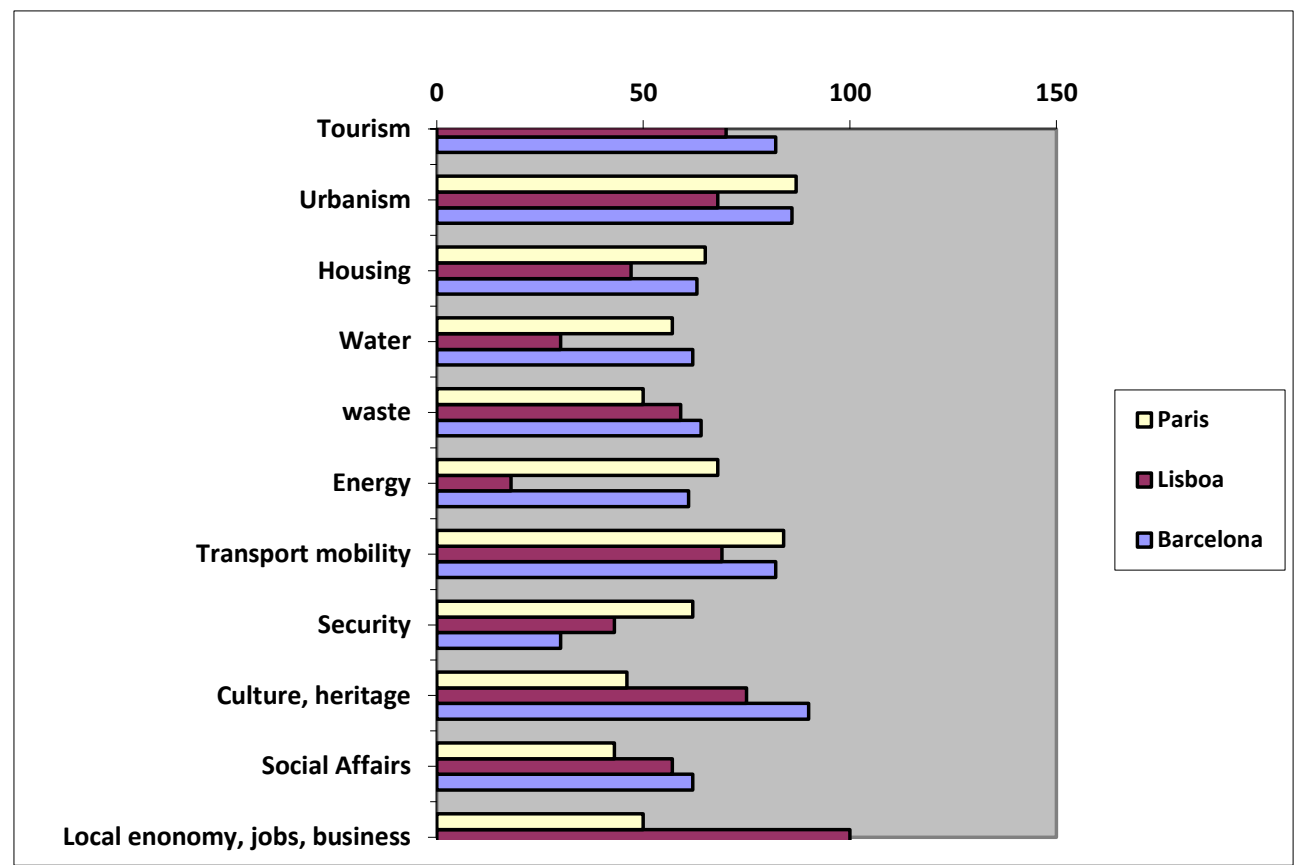

Figura 1 - Areas are involved on the sustainability of tourism

Source: Adapted from World Tourism \& Travel Council (2017) City travel \& tourism impact 2017 Europe. London

Following a comparative analysis of the influencing factors in tourism sustainability policies, on three tourist destinations - Barcelona, Lisbon, and Paris - the following situation was reached - see Figure 2.

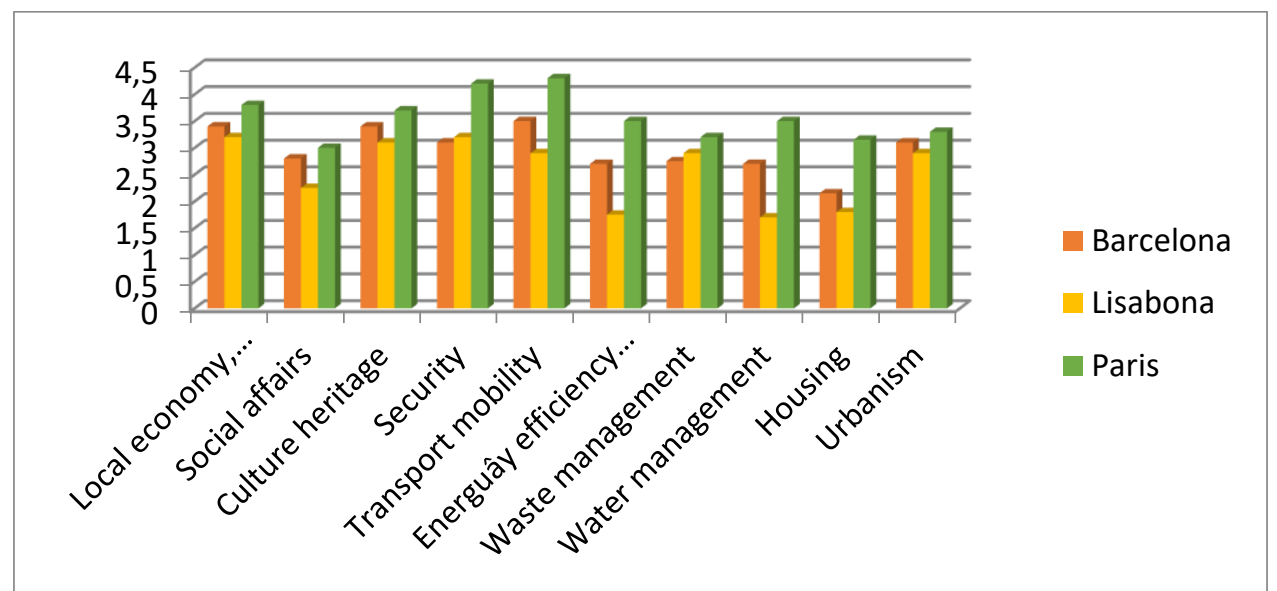

Figure 2 The influencing factors in tourism sustainability policies (1 low to 5 high) Source: Adapted from World Tourism \& Travel Council (2017) City travel \& tourism impact 2017 Europe. London 
We can note that tourism decision-makers have shared common concerns, but local tourism policies are quite diverse among cities. The problems are generated by the lack of coordination between the various departments of the city, there is ample room for improvement in terms of integrating various urban policies into tourism strategies.

The phenomenon of overcrowding is thought of as the enemy of sustainability in tourism being characterized by high concentration of tourists and tourist services in historical or commercial specific areas. This overcrowding in some areas could lead to an increase in the cost of living for locals, the replacement of houses with tourist apartments, a higher demand for certain products and services, which would have the effect of reducing the quality of life for locals. The phenomenon of migration of highly skilled labor, wealthy tourists and students contributes to rising rental prices and, consequently, forces lower-income residents to migrate to other urban / rural areas. In response to this problem, strategy makers (Colomb, C. and Novy, J.,2017) need to think of innovative planning policies, such as:

- Metropolitan tourism policies to spread tourists to wider geographical areas,

- Spatial planning policies through the development of tourist objectives on large territorial areas,

- Spatial hotel planning for the management of the accommodation offer,

- High taxation in areas with high tourist agglomeration

- Local businesses planning, maintaining a correct balance between their permanent and seasonal nature,

- Urban mobility strategies for tourist areas to prevent congestion around the main attraction areas.

Tourism is a large consumer of natural resources (water, energy, food etc.), therefore, it is necessary to reduce excessive consumption and environmental pollution resulting from tourism activities. Tourist mobility is a serious problem, as it is based on high-carbon forms of transport (planes, cruises, cars, etc. Therefore, it is very important to develop sectoral mobility plans for tourists by:

- Introduction of tourism indicators in the development of public transport policies.

- Adaptation of public and collective forms of transport during the seasonal periods, including the management of tourist bus traffic avoiding overcrowding and pollution of local sites.

- Promoting the use of eco-transport (eg. bicycles) and stimulating pedestrian routes

- Ensuring waste recycling strategies, banning the use of disposable plastics

- Energy and water efficiency measures in hotels, transport and tourism facilities.

\section{Conclusions}

To be supported by local communities and civil society, tourism should make a positive contribution to the sustainable development of the area in which it is practiced. Therefore, local community leaders can do this if they take into account a number of recommendations:

- Identify the main governmental / regional / local actors responsible for the design and implementation of tourism policies related to social and environmental sustainability. 
- Analyze the integration of sustainability [environmental and social] in tourism strategies and the impact of tourism growth on the area.

- Analyze the perceptions of stakeholders about the role of sustainability in urban tourism policies;

- Identifying innovative strategies and policy instruments that address issues related to sustainable tourism;

- Proposed a set of recommendations to promote policy making and good governance for sustainable tourism.

The assessment of sustainability is the first step in understanding the real impact of tourism on local / regional destination. This should be done in collaboration with external experts, monitoring and transparency are essential to gather information and to properly inform local sustainability decision makers. Policy coherence and cross-cutting coordination between different local development strategies are needed, by strengthening destination management beyond economic promotion and marketing. Mitigation and prevention of negative environmental impact should be ensured by integrating different policies, strategies and practices related to natural resource management and social equity objectives. Trends in the quantitative growth of tourism must be redefined from the perspective of sustainability. The exponential increase in the number of tourists in a destination will further increase the environmental and social conflicts, will endanger the quality of the destination. Mobility and transport models should be modified to reduce carbon emissions related to low-cost airlines, road transport and cruises. National and local transport authorities need to implement clean mobility and public transport to cope with targeted climate change. The regulation of the real estate market and the shared economy is another key issue in which there is a combination of regulatory and legal policies at local, national, and European level that must ensure access to housing for permanent residents.

\section{References}

1. Ashworth, G. and Page, S.J. (2011) Urban tourism research: Recent progress and current paradoxes, Journal of Tourism Management, 32, 1-15.

2. Câmara Municipal de Lisboa (2017) Atlas Social de Lisboa. Lisboa. Entidade Regional de Turismo da Regiăo de Lisboa/Visitlisboa (2015) Strategic Tourism Plan for the Lisboa Region. Lisboa.

3. Colomb, C. and Novy, J. (2017) Urban Tourism and its discontents. An introduction in Colomb, C. and Novy, J. (2017) Protest and Resistance in the Tourist City. Routledge Editure.

4. Dredge, D, Gyimóthy, S., Birkbak, A., Jensen, T. E. \& Madsen, A. K. (2016) The impact of regulatory approaches targeting collaborative economy in the tourism accommodation sector: Barcelona, Berlin, Amsterdam and Paris, Impulse Paper No 9 prepared for the European Commission DG GROWTH. Aalborg University, Copenhagen.

5. Marie de Paris (2016) 2022 Tourism Strategy Plan, Development Plan. Paris.

Rutty, M. et al. (2014) The global effects and impacts of tourism. An overview in Hall, M., Göosling, S. and Scott, D. (2014) 7 The Routledge Handbook of Tourism and Sustainability. Routledge, New York. 
6. Vera Pais (2018) Lisbon. Urban Tourism and Sustainability Policies. Presentation at Tourism Ecoforum, May 2018, Barcelona. http://www.global-ecoforum.org/tef2018

7. Williams, A. (2013) Mobilities and Sustainable Tourism: path-creating or pathdependent relationships?, Journal of Sustainable Tourism, 21:4, 511-53.

8. UNWTO (2018) European Union Tourism Trends 2017, World Tourism Organization.

9. World Tourism \& Travel Council (2017) City travel \& tourism impact 2017 Europe, London.

10. http://ajuntament.barcelona.cat/pla-allotjaments-turistics/es/

11. http://pro.parisinfo.com/content/download/149746/16039462/version/1/file/ Strategie-tourisme-2022-Plan-d\%27actions.pdf

12. https://ajuntament.barcelona.cat/turisme/en/strategic-plan/documents

13. https://pro.parisinfo.com/actualites/actualite-touristique/Dossiers/schematouristique-paris-2022. 